\title{
Hemocytic studies on the synergistic effect of the entomopathogenic nematode species, Steinernema carpocapsae and gamma radiation on the greater wax moth, Galleria mellonella (L.) larvae
}

\author{
H. M. Salem¹, M. A. Hussein² , S. El. Hafez² , M. A. Hussein ${ }^{3}$ and R. M. Sayed ${ }^{1 *}$ (D)
}

\begin{abstract}
Combined effect of substerilizing doses of gamma radiation (40 and $100 \mathrm{~Gy}$ ) and different concentrations of the entomopathogenic nematode, Steinernema carpocapsae BA2 (20 and $40 \mathrm{lJs} / \mathrm{ml})$ on the hemocyte count of the greater wax moth, Galleria mellonella (L.) larvae was studied. Eight types of hemocytes were described in the hemolymph of the normal larvae of G. mellonella. Prohemocytes were the predominant type, while the cystocytes were the rare ones. Morphological malformations and changes in the number of each hemocyte type were observed in F1 larvae (of irradiated male parent pupae with 40 or $100 \mathrm{~Gy}$ ) or larvae treated with different concentrations of the S. carpocapsae BA2 (normal or F1 larvae); these alterations were increased by increasing the radiation dose or the nematode concentration that led to increase the susceptibility of the larvae to the nematode. Therefore, it could be concluded that integration of entomopathogenic nematodes and gamma radiation may serve as integrated control program for G. mellonella.
\end{abstract}

Keywords: Steinernema carpocapsae, Gamma radiation, Galleria mellonella, Hemocytes

\section{Background}

Entomopathogenic nematodes (EPNs) are a welcome addition to the natural-enemy arsenal. They are generally specific on insects, not environmentally hazardous, compatible with other biological and chemical agents, can seek pests in cryptic habitats, and can be commercially produced in large quantities (Gaugler and Kaya 1990, Laznik et al. 2012, Laznik and Trdan 2017).

Many non-classic control methods are currently used, such as physical and/or biological control of pests in field and store. The use of irradiation technique as a

\footnotetext{
* Correspondence: rehab.omar@yahoo.com

'Natural Products Research Department, National Center for Radiation

Research and Technology, Atomic Energy Authority, Cairo, Egypt

Full list of author information is available at the end of the article
}

physical control method is cheaper, safer, and more reliable than chemical methods. Parasitism by nematodes has variable deleterious effects on their insect hosts including the following: sterility, reduced fecundity, longevity, flight activity, delayed development, and other behavioral, physiological, and morphological changes (Gaugler 2002).

Combining EPNs with gamma radiation has resulted in successful control strategies (Salem et al. 2008; Sayed 2008, 2011; and Sayed et al. 2015). The hemocytes of insects have been reported to play a role in cellular defense against foreign materials by phagocytosis or encapsulation; they may be concerned in the formation of connective tissue and activation of prothoracic gland before molting (Charles 1971). 
The high interest in biological means of controlling insects intensifies the need for investigating the response of insects to diseased organisms. Much work has been done on changes in the hemocytes picture, following injury, and hemorrhage in insects attacked by parasites (Salt 1970).

The greater wax moth, Galleria mellonella (L.) larvae, were recorded to be a good model of organisms for studying host response to pathogens due to their rapid growth, high fertility, size, and short life cycle (Mukherjee et al. 2010).

The aim of this work was to investigate the immune response of G. mellonella larvae to gamma radiation and the EPNs by estimating the differential hemocyte counts in larvae.

\section{Materials and methods} Insect and entomopathogenic nematodes

Galleria mellonella (L.) larvae were obtained from the infested hives and reared in the laboratory at $28 \pm 2{ }^{\circ} \mathrm{C}$ and $65 \pm 5 \% \mathrm{RH} \%$ as described by Glazer and Lewis (2000). Steinernema carpocapsae BA2 was originally obtained from the National Research Center (NRC), Pests \& plant Protection Department, Giza, Egypt.
Table 1 Total hemocyte count $/ \mathrm{mm}^{3}$ of blood from Galleria mellonella larvae treated with gamma radiation alone or combined with the entomopathogenic nematode, Steinernema carpocapsae BA2

\begin{tabular}{llll}
\hline $\begin{array}{l}\text { Treatment } \\
\text { radiation } \\
\text { doses (Gy) }\end{array}$ & \multicolumn{3}{l}{$\mathrm{THC} / \mathrm{mm}^{3} \times 10^{3}$} \\
\cline { 2 - 4 } & Gamma rays & \multicolumn{3}{l}{ S. carpocapsae BA2 } \\
\cline { 3 - 4 } & & $20 \mathrm{IJ}$ & $40 \mathrm{IJ}$ \\
\hline Control & $32.08 \pm 0.54^{\mathrm{a}}$ & $13.13 \pm 0.34^{\mathrm{a}}$ & $10.91 \pm 0.75^{\mathrm{a}}$ \\
40 & $21.75 \pm 0.22^{\mathrm{b}}$ & $10.4 \pm 0.32^{\mathrm{b}}$ & $9.2 \pm 0.57^{\mathrm{b}}$ \\
100 & $20.56 \pm 0.29^{\mathrm{b}}$ & $8.73 \pm 0.21^{\mathrm{c}}$ & $5.61 \pm 0.2^{\mathrm{c}}$ \\
\hline
\end{tabular}

Letters indicate the variance between the means (Duncan's multiple range test). Values represent the mean \pm S.E. of 3 replicates for each group

\section{Irradiation technique and bioassay experiments Irradiation technique}

Full-grown pupae were irradiated by 40 and $100 \mathrm{~Gy}$, using the Gamma cell irradiation unit ( ${ }^{60} \mathrm{Co}$ source), located at the National Center for Radiation Research and Technology (NCRRT), Atomic Energy Authority, Cairo, Egypt. The dose rate was $6.6 \mathrm{kGy} / \mathrm{h}$.

\section{Bioassay experiments}

Normal 4th instar larvae and the larvae resulted from irradiated male parent pupae at doses 40 and $100 \mathrm{~Gy}$ (F1

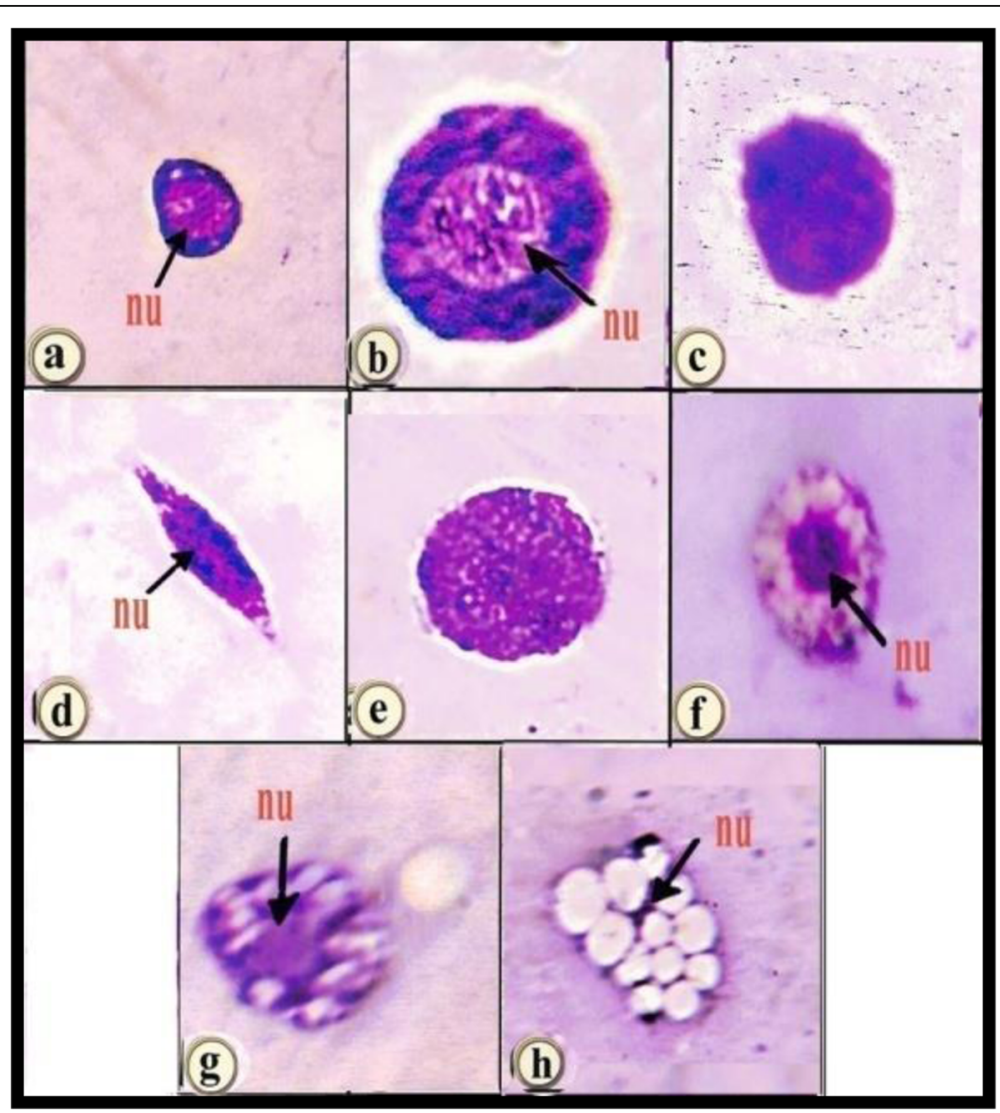

Fig. 1 Normal hemocytes of Galleria mellonella larvae $(x=1600)$. a Prohemocytes, b plasmatocytes, c granulated cells, $\mathbf{d}$ spindle cells, e spherule cells, $\mathbf{f}$ adipohemocytes, $\mathbf{g}$ oenocytoids, $\mathbf{h}$ cystocytes. nu indicates the hemocyte nucleus 
larvae) were treated by the nematode at 2 concentrations: 20 and $40 \mathrm{IJs} / \mathrm{ml}$. Untreated larvae were used as control. Treated and control larvae were incubated at 25 $\pm 1{ }^{\circ} \mathrm{C}$.

\section{Preparation of blood film}

To determine the differential hemocytes and the pathological changes resulted from radiation and nematode treatments, hemolymph smears were taken from 4th instar larvae. A drop of blood was spread as a thin film by the aid of a cover slip, air dried, fixed in absolute methanol for $5 \mathrm{~min}$, stained in Giemsa stain for $35 \mathrm{~min}$ and the stain was flushed off by distilled water (Abdel-Rahman 1978).

\section{Counting method}

The proleg on the abdominal segment was cut by a fine pair of scissors, and blood was allowed to ooze on a clean, grease free, glass microscopic slide. The hemolymph was quickly drawn up to the 0.5 mark in a Thoma white blood cell dilution pipette and immediately diluted to 11 mark with Turek solution 1-2 \%glacial acetic acid, slightly colored with gentian violet. The first two or three drops of this solution were discarded; the hemocytes were counted at the 4 corners and multiplied by a factor of 50 to get the number of cells per cubic millimeter. If the cells were clumped or unevenly distributed in the chamber, the preparation was discarded, as described by Rizk (1991).

\section{Statistical analysis}

The data were statistically analyzed by analysis of variance $(F)$, followed by Duncan's multiple range test to examine the significant differences between treatments. The $5 \%$ level of probability was used in all statistical tests, using COSTAT computer program.

\section{Results and discussion}

Total hemocyte count (THC)

Total number of hemocytes of G. mellonella larvae decreased gradually by increasing the dose of radiation applied to parent male pupae as compared to the control (Table 1). After nematode treatments (20 and $40 \mathrm{IJs} / \mathrm{ml}$ ), the total hemocyte counts decreased significantly and more decreases occurred when they applied to F1 larvae of irradiated parent male pupae (40 and $100 \mathrm{~Gy}$ ).

The present study showed that increasing parental radiation dose or treatment of F1 larvae with $S$. carpocapsae BA2 significantly decreased the THC of 4th instar larvae or F1 of G. mellonella larvae. These investigations

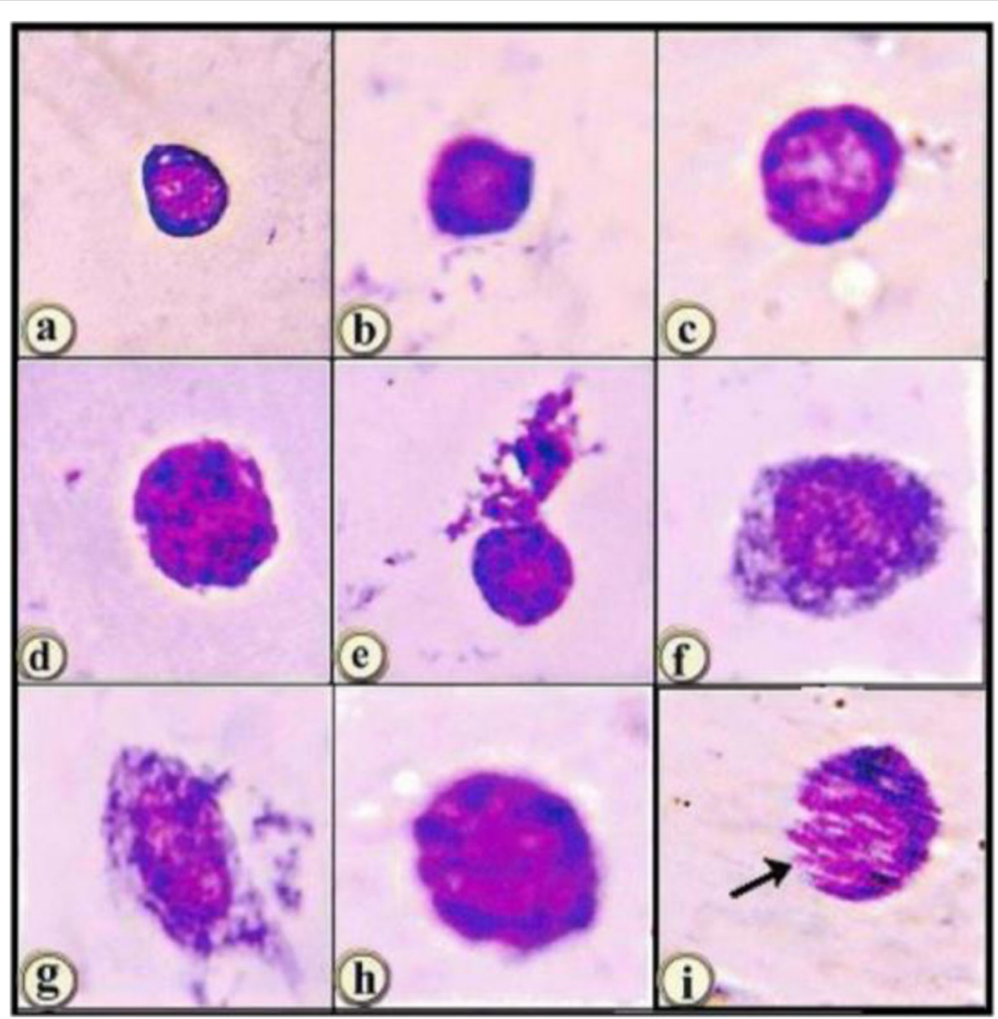

Fig. 2 Morphological changes in prohemocytes $(x=1600$ ). a Normal: small, round to slightly ovoid prohemocyte cell. b 40 Gy, c 100 Gy, d BA2 $40 \mathrm{lJs} / \mathrm{ml}$, e $40 \mathrm{~Gy}+\mathrm{BA} 220 \mathrm{lJs} / \mathrm{ml}, \mathbf{f} 100 \mathrm{~Gy}+\mathrm{BA} 220 \mathrm{Js} / \mathrm{ml}, \mathbf{g} 40 \mathrm{~Gy}+\mathrm{BA} 240 \mathrm{lJs} / \mathrm{ml}, \mathbf{h} 100 \mathrm{~Gy}+$ BA2 $20 \mathrm{lJs} / \mathrm{ml}$, and i $100 \mathrm{~Gy}+\mathrm{BA} 240 \mathrm{lJs} / \mathrm{ml}:$ destruction of the cell membrane and presence of vacuoles (arrow) 


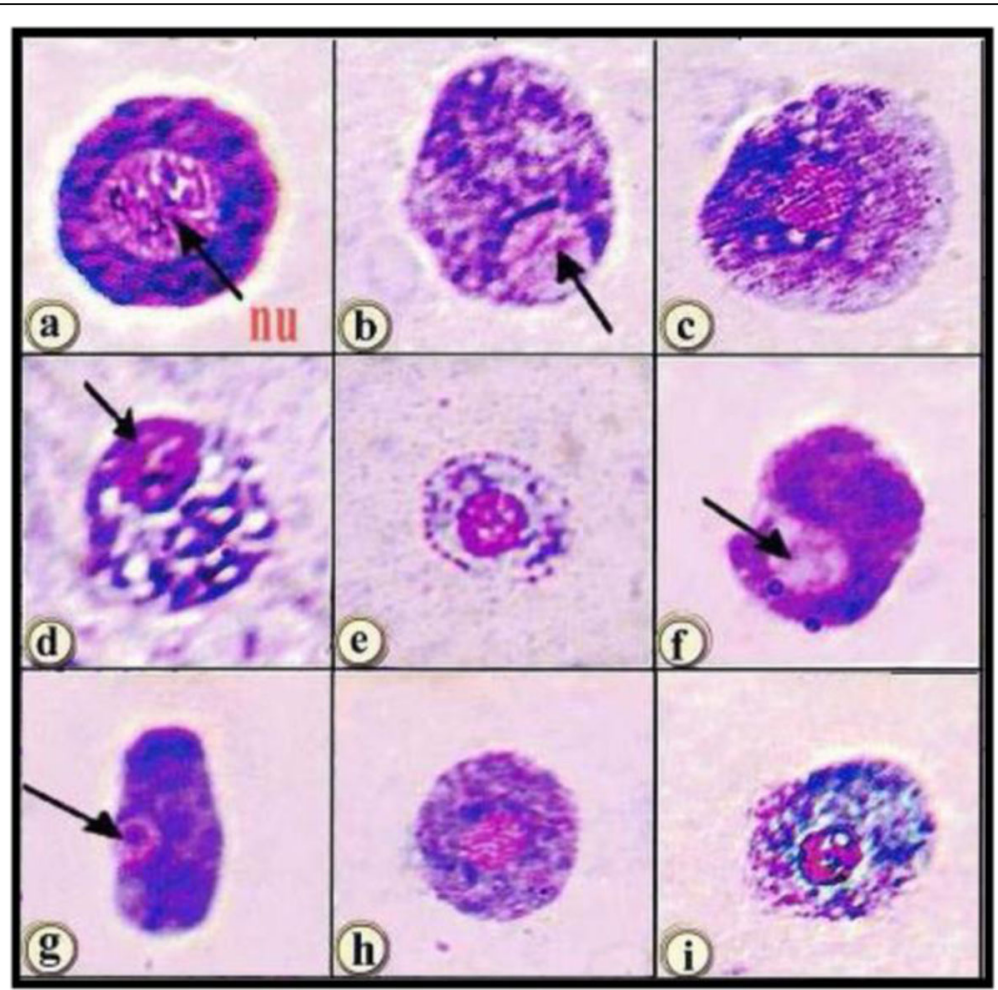

Fig. 3 Abnormalities in plasmatocytes $(x=1600)$. a Normal: round with central nucleus plasmatocytes. b $40 \mathrm{~Gy}, \mathbf{c} 100 \mathrm{~Gy}$, and d BA2 $20 \mathrm{IJS} / \mathrm{ml}$ : vacuolation of cytoplasm (arrow). e BA2 $40 \mathrm{Js} / \mathrm{ml}, \mathbf{f} 40 \mathrm{~Gy}+\mathrm{BA} 220 \mathrm{Js} / \mathrm{ml}, \mathbf{g} 40 \mathrm{~Gy}+\mathrm{BA} 240 \mathrm{JJ} / \mathrm{ml}, \mathbf{h} 100 \mathrm{~Gy}+\mathrm{BA} 220 \mathrm{lJs} / \mathrm{ml}$, and i $100 \mathrm{~Gy}+\mathrm{BA} 2$ $40 \mathrm{JJs} / \mathrm{ml}$ : the cell takes an oval shape with acentric nucleus (arrow). nu indicates the hemocyte nucleus

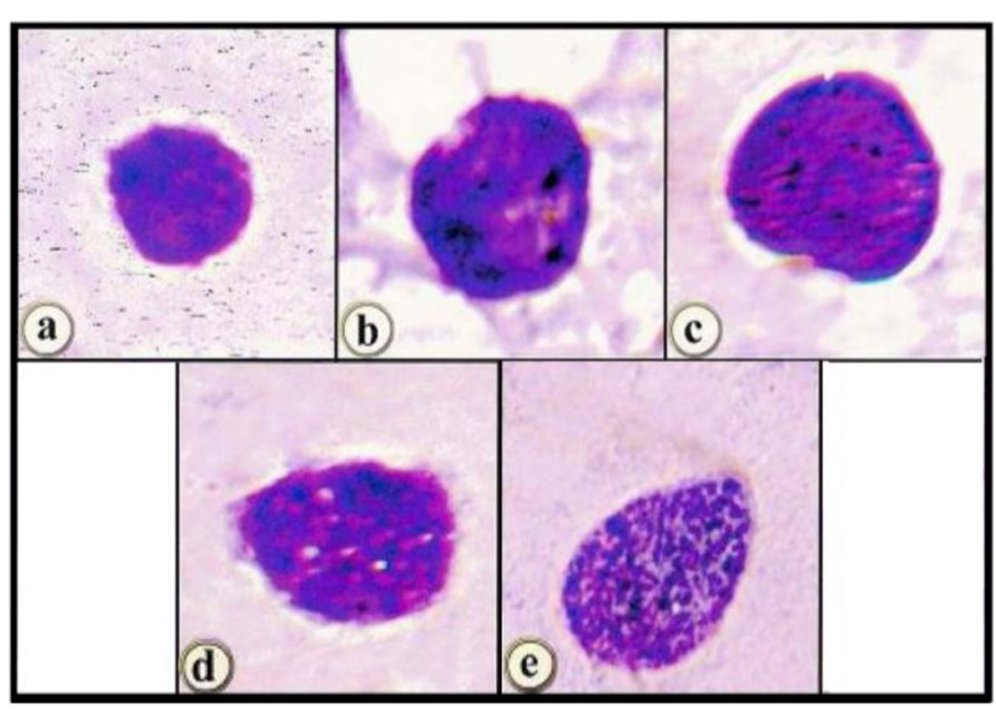

Fig. 4 Morphological changes in granulated cells $(x=1600)$. a Normal granulocytes: slightly round, with undifferentiated cytoplasm and nucleus granulocyte. b 40 Gy c 100 Gy and d BA2 $20 \mathrm{lJs} / \mathrm{ml}$ and e BA2 $40 \mathrm{lJs} / \mathrm{ml}$ treatments showing granulocyte in oval shape with cytoplasm vacuolation 


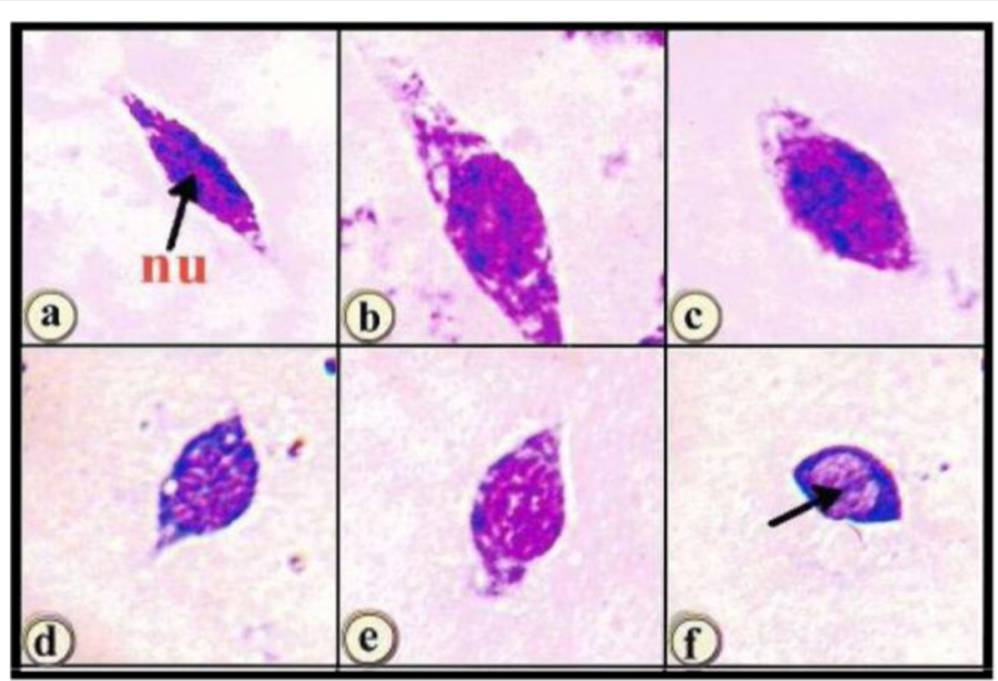

Fig. 5 Morphological changes in spindle cells $(x=1600)$. a Normal: spindle shaped cells with spindle nucleus (arrow). b 40 Gy, c 100 Gy, d BA2 20 IJs/ml, e BA2 $40 \mathrm{Js} / \mathrm{ml}$, and (f) $40 \mathrm{~Gy}+\mathrm{BA} 220 \mathrm{JJ} / \mathrm{ml}$ : the spindle cell takes irregular shape approximately round nucleus (arrow). nu indicates the hemocyte nucleus

were in agreement with those obtained by Souka et al. (1993), Ayaad et al. (2001), Sayed (2008), and El-Sonbaty et al. (2016).

\section{Galleria mellonella hemocyte type}

Hemocytes were distinguished based on their morphological characteristics and staining affinity. Eight types were found in 4th instar larvae of G. mellonella (Fig. 1): (a) prohemocytes: were small, round to slightly ovoid cells, with undifferentiated cytoplasm. The single, round nucleus with dense, homogenous chromatin is usually enlarged in size leading to formation of macronucleus, which in turn sparing the cellular cytoplasm; (b) plasmatocytes: characterized by their round shape. The nucleus with dark stains, round with punctuate, or granular chromatin and usually central in position; (c) granulated cells: were slightly round, characterized by the undifferentiated cytoplasm and nucleus; (d) spindle cells: spindle-shaped cells distinguished by the presence of very large, distinct, usually spindle nucleus $(\mathrm{nu})$, mostly

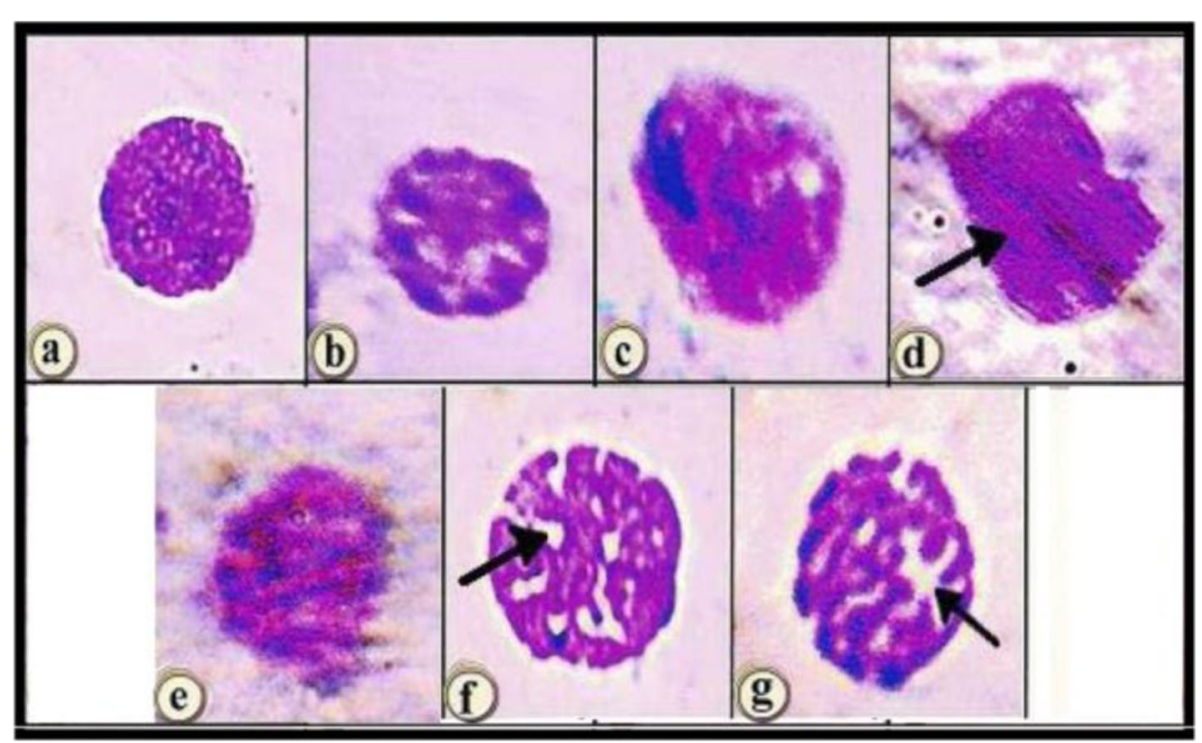

Fig. 6 Morphological changes in spherule cells $(x=1600)$. a Normal cells: round with undistinguished nucleus b 40 Gy and c 100 Gy: increased the cell size. $\mathbf{d}$ BA2 $20 \mathrm{lJs} / \mathrm{ml}$ induced cytoplasmic vacuolation (arrow) and e BA2 $40 \mathrm{lJs} / \mathrm{ml}$ : irregular shape of the sphere cell. f $40 \mathrm{~Gy}+$ BA2 20 $\mathrm{IJs} / \mathrm{ml}$ and $\mathbf{g} 40 \mathrm{~Gy}+\mathrm{BA} 240 \mathrm{Js} / \mathrm{ml}$ : increased the cell size with cytoplasm vacuolation (arrow) 
appearing as a solid purple structure; (e) spherule cells: were round with undistinguished nucleus. After Giemsa stain, they appeared in dark pink color; (f) adipohemocytes: were rounds containing variable amounts of refringent fat droplets and several other non-lipid inclusions; (g) oenocytoids: were slightly round characterized by round, large, and approximately centric nucleus with homogenous chromatin. The cytoplasm contained numerous granular inclusions and filled with intricated canaliculi; and (h) cystocytes: were extremely fragile cells with a single, small, irregular nucleus in envelope containing distinct, round, acidophilic inclusions.

\section{Morphological effects of gamma radiation and/or EPNs on Galleria mellonella hemocytes}

1- Prohemocytes: prohemocytes from F1 larvae (resulted from irradiated male pupae mated with normal female) and F1 larvae treated with $S$. carpocapsae exposed elongation in the shape, destruction of the cell membrane, and evidence of vacuoles (Fig. 2).

2- Plasmatocytes: morphological changes were observed in plasmatocytes in F1 larvae after different treatments. Generally, radiation with $40 \mathrm{~Gy}$ and $100 \mathrm{~Gy}$ to the parent male pupae caused the cell to be enlarged or took slightly oval shape. The nucleus lost its central position and moved to the cell wall (Fig. $3 \mathrm{~b}$ and c). S. carpocapsae affects plasmatocytes in the same way of gamma radiation inducing vacuolation of cytoplasm. The combined effect of nematodes and radiation would be more destructive to cells than using each of them only as the cells become irregular in shape (Fig. 3).

3- Granulated cells: gamma irradiation (40 and 100 Gy) of parent pupae significantly increased the size of granulated cells in the hemolymph of F1 G. mellonella larvae. Granulated cells enlarged or may take oval shape as a result of S. carpocapsae treatment alone (Fig. $4 \mathrm{~d}$, e). The combined effect of gamma radiation and S. carpocapsae (20 and $40 \mathrm{IJs} / \mathrm{ml}$ ) led to disintegration and disappearance of granulated cells.

4- Spindle cells: the nucleus of the spindle cells became slightly round (Fig. $5 \mathrm{~b}$ and c). Moreover, they showed notable changes in their shape, when S. carpocapsae BA2 were applied alone to G. mellonella larvae. The combined effect of gamma radiation and S. carpocapsae led to disappearance of the spindle cells, except the combination of $40 \mathrm{~Gy}$ and $20 \mathrm{IJs} / \mathrm{ml}$ of $S$. carpocapsae, the spindle cells became compressed in size with approximately round nucleus (Fig. $5 \mathrm{f}$ ).

5- Spherule cells: irradiation of parent pupae, S. carpocapsae, and their combination (40 Gy with 20 and 40 $\mathrm{IJs} / \mathrm{ml}$ ) affected the shape of the spherule cells of the larvae. The changes were enlargement, losing the round shape and appearance of vacuoles in the cell. The other combinations of gamma radiation (100 Gy) and EPN (20

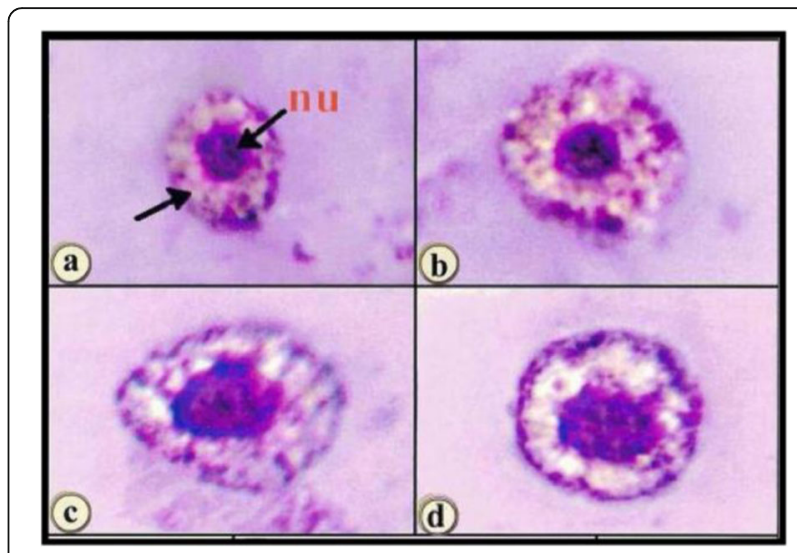

Fig. 7 Abnormalities in adipohemocytes $(x=1600)$. a Normal: round containing variable amounts of refringent fat droplets (arrow). b 40 Gy and c $100 \mathrm{~Gy}$; and d BA2 $20 \mathrm{Js} / \mathrm{ml}$ : increased the cell size than in control. nu indicates the hemocyte nucleus

and $40 \mathrm{IJs} / \mathrm{ml}$ ) resulted in disappearance of the spherule cells (Fig. 6).

6- Adipohemocytes: gamma radiation of pupae with 40 and 100 Gy and S. carpocapsae $(20 \mathrm{IJs} / \mathrm{ml}$ ) treatments increased the size of adipohemocytes in larvae (Fig. 7). Adipohemocytes vanished from the hemolymph of G. mellonella larvae under S. carpocapsae BA2 (40 IJs $/ \mathrm{ml})$ and under the combined effect of gamma radiation (40 and $100 \mathrm{~Gy}$ ) and EPN (20 and $40 \mathrm{IJs} / \mathrm{ml}$ ).

7- Oenocytoids: exposure of G. mellonella pupae to $40 \mathrm{~Gy}$ induced enlargement of the cell size in the hemolymph of F1 larvae. When the pupae exposed to 100

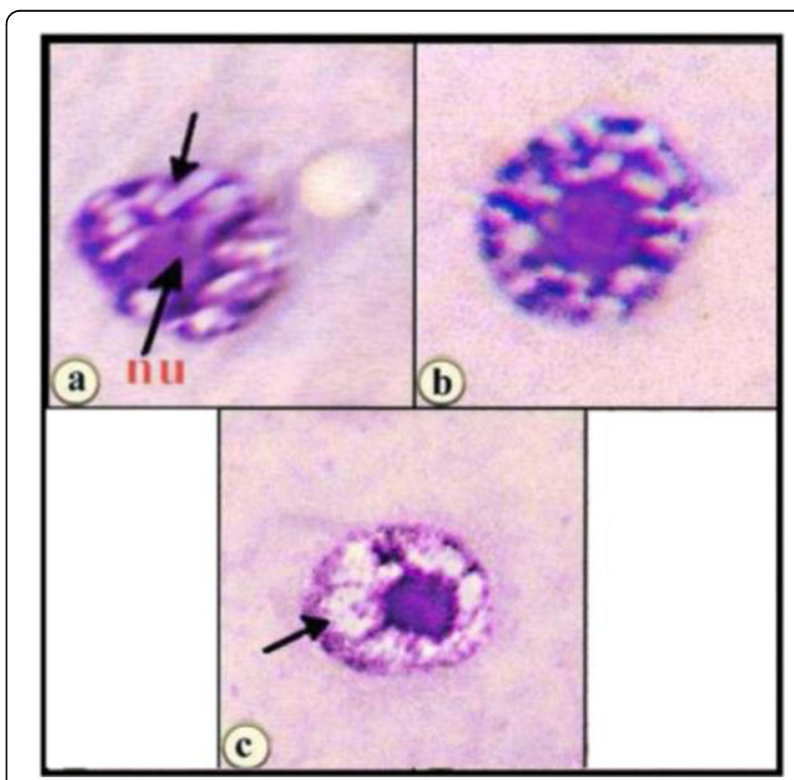

Fig. 8 Morphological changes in oenocytoids $(x=1600)$. a Normal: oenocytoid is slightly round with round, large, and approximately centric nucleus (arrow). b 40 Gy: increase in the cell size. c 100 Gy (nu indicates the hemocyte nucleus) 


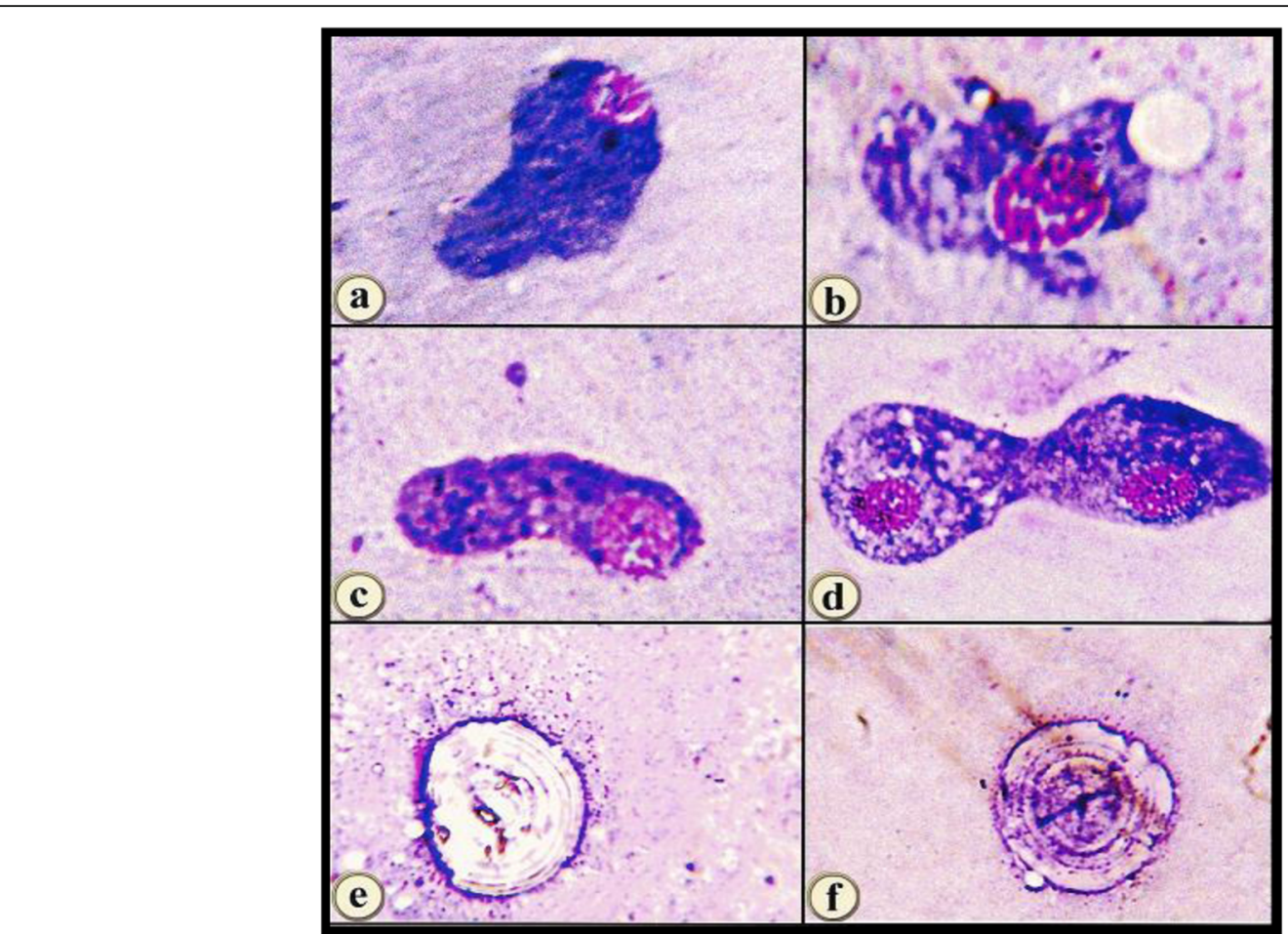

Fig. 9 Response of the hemocytes to the nematodes' treatments: $\mathbf{a}$ and $\mathbf{b}$ phagocytosis, $\mathbf{c}$ and $\mathbf{d}$ mitotic division, and $\mathbf{e}$ and $\mathbf{f}$ encapsulation of foreign body. $(x=1600)$

Gy, oenocytoid cell enlarged and the cytoplasm degranulated (Fig. 8). The treatments with S. carpocapsae alone or in F1 G. mellonella larvae lysed oenocytoids.

8- Cystocytes: treatment with gamma radiation to parent pupae with 40 and 100 Gy or larvae treatment $S$. carpocapsae BA2 caused completely disappearance of cystocytes from the hemolymph of G. mellonella larvae.

In case of nematode's treatments, a hemocyte's response appeared as immunocompetent cells. This response was by phagocytosis (Fig. 9 a and b) or by encapsulation of foreign body (Fig. 9 e and f) or by increasing the mitotic division (Fig. $9 \mathrm{c}$ and d).
The observed pathological conditions in the infected hemocytes are characterized as follows: (1) enlargement or elongation of the cell, (2) vacuolization and degeneration of the cytoplasm, and (3) lyses of the cell membrane. The changes were a response of the actions of gamma radiation and the EPNs. Similar results were previously indicated by Rizk (1991), Salem et al. (2014), and El-Sonbaty et al. (2016). The reason of hemocyte vacuolations by the EPN was explained by Ribeiro et al. (2003) who reported intracellularly hemocyte changes, such as selective vacuolation of the endoplasmic reticulum, cell swelling, and cell death by colloid-osmotic lysis in

Table 2 Hemocyte percentage of F1 Galleria mellonella larvae (irradiated parent male pupae with 40 or $100 \mathrm{~Gy}$ ) alone or combined with Steinernema carpocapsae BA2 (20 and $40 \mathrm{lJs} / \mathrm{ml}$ ) treatments

\begin{tabular}{llllllllll}
\hline Treatments Cell type & Control & $40 \mathrm{~Gy}$ & $100 \mathrm{~Gy}$ & $20 \mathrm{IJs} / \mathrm{ml}$ & $40 \mathrm{IJs} / \mathrm{ml}$ & $40 \mathrm{~Gy}+20 \mathrm{IJs} / \mathrm{ml}$ & $40 \mathrm{~Gy}+40 \mathrm{IJs} / \mathrm{ml}$ & $100 \mathrm{~Gy}+20 \mathrm{IJs} / \mathrm{ml}$ & $100 \mathrm{~Gy}+40 \mathrm{IJ} / \mathrm{ml}$ \\
\hline Prohemocytes & 49.56 & 49.59 & 50.29 & 74.41 & 82.81 & 85.71 & 92.49 & 95.27 & 96.55 \\
Plasmatocytes & 23.16 & 23.69 & 25.12 & 13.84 & 10.29 & 8.23 & 7.51 & 4.73 & 3.45 \\
Granulocytes & 5.62 & 5.55 & 4.81 & 2.64 & 1.55 & 0 & 0 & 0 & 0 \\
Spindle cells & 7.9 & 7.9 & 7.8 & 5.588 & 3.817 & 4.46 & 0 & 0 & 0 \\
Spherule cells & 3.05 & 3.02 & 2.37 & 2.2 & 1.53 & 1.59 & 1 & 0 & 0 \\
Adipohemocytes & 7.15 & 7.06 & 6.39 & 1.32 & 0 & 0 & 0 & 0 & 0 \\
Oenocytoids & 3.27 & 3.19 & 3.17 & 0 & 0 & 0 & 0 & 0 & 0 \\
Cystocytes & 0.28 & 0 & 0 & 0 & 0 & 0 & 0 & 0 & 0
\end{tabular}

Values represent the mean of percentages of 3 replicates for each group 
Spodoptera littoralis (Boisd.) infected with $X$. nematophilus, the symbiotic bacteria of $S$. carpocapsae.

\section{Differential hemocyte counts (DHCs) in G. mellonella larvae}

The percentages of the distinguished hemocytes in normal 4th instar larvae of G. mellonella and after different treatments with gamma radiation or/and S. carpocapsae are presented in Table 2. Results showed that gamma irradiation of G. mellonella male pupae raised the percentage of prohemocytes and plasmatocytes, while decreased the percentages of the other hemocytes in the hemolymph of the 4th instar larvae. S. carpocapsae treatment led to an increase in the prohemocyte percentage and decrease in the percentages of the other hemocyte type. The treatment of F1 larvae with $S$. carpocapsae resulted in excess in prohemocyte percentage with reduction in plasmatocytes, spindle cells, and spherule cell percentages. Moreover, these treatments caused disappearance of granulocytes, adipohemocytes, oenocytoids, and cystocytes.

The present study on DHCs of normal G. mellonella larvae treated with different radiation doses or the EPN (BA2) showed an increase in the percent of prohemocytes. While the other types decreased with increasing the treatments. Obtained results were in accordance with those of Rizk (1991) and Salem et al. (2008 and 2014).

It is well known that the stimulatory factor resulted from nematode infection stimulates the hemopietic organs to form new hemocyte generations and/or mitosis of the circulating hemocytes (Lackie 1988). Therefore, the increase in prohemocytes is a result of mitosis in response to nematode treatment. As prohemocytes are hypothesized to be stem cells that differentiate into one or more of the aforementioned hemocyte types (Lavine and Strand 2002), this is in accordance with the results of Ayaad et al. (2001). Regarding to the reports of Matha et al. (1990) and El-Maasarawy et al. (1995) that spherulocytes, spindle cell, and plasmatocytes are considered as immunocompetent cells in G. mellonella; therefore, the decrease in plasmatocytes, granulocytes, spindle cells, and sphere cells in this study may reflect their importance in phagocytosis and encapsulation. The sharply decrease in adipohemocytes, oenocytoids, and cystocytes may be due to the toxin released by the symbiotic bacteria (Dunphy and Webster 1988).

The remarkable decrease in DHCs of 4th instar G. mellonella larvae, increased with gamma irradiation doses (40-100 Gy), is in agreement with that of Rizk (1991) and El-Sonbaty et al. (2016) that may be due to the effect of gamma radiation on the physiological condition of the body (Al Khalaf and AbdelBaki 2013).

\section{Conclusion}

G. mellonella larvae resulted from irradiated parent at high irradiation doses became more susceptible to the infection with the nematodes. Radiation exposure and nematode infection reduced the immune response of $G$. mellonella larvae. So, it would be suggested that integration of $S$. carpocapsae and gamma radiation can be an ideal eco-friendly pest control program.

\section{Abbreviations}

BA2: Steinernema carpocapsae BA2; F1: First progeny from irradiated male parent pupae; Gy: Gray; IJs: Infective juveniles of S. carpocapsae

\section{Acknowledgements}

Not applicable

Authors' contributions

All authors were equally contributed. The author(s) read and approved the final manuscript.

\section{Funding}

Not applicable

Availability of data and materials

Not applicable

Ethics approval and consent to participate

Not applicable.

\section{Consent for publication}

Not applicable.

\section{Competing interests}

The authors declare that they have no competing interests.

\section{Author details}

${ }^{1}$ Natural Products Research Department, National Center for Radiation Research and Technology, Atomic Energy Authority, Cairo, Egypt.

2Department of Entomology, Faculty of Science, Ain Shams University, Cairo, Egypt. ${ }^{3}$ Pests and Plant Protection Dept., National Research Center, Giza,

Egypt.

Received: 7 March 2020 Accepted: 22 April 2020

Published online: 30 April 2020

\section{References}

Abdel-Rahman AM (1978) The haemocytes of Aedes caspius. Palls Bull Fac Sci Cairo University 51(1):95-100

Al Khalaf AA, AbdelBaki SM (2013) Gamma irradiation effects on larvae of the rice moth, Corcyra cephalonica (Staint) (Lepidoptera: Pyralidae). J Entomol Nematol 5(4):45-49

Ayaad TH, Darrah MA, Shaurub EH, HA El-S (2001) Effects of the entomopathogenic nematode, Heterorhabditis bacteriophora HP 88 and Azadirachtin on the immune defense response and prophenoloxidase of Parasarcophaga surco!lfi larvae (Diptera: Sarcophagidae). J Egypt Soc Parasitol 31(1):295-325

Charles J (1971) Haemolymph arthroapoda. Chem Zool 6:64-118

Dunphy GB, Webster JM (1988) Lipopolysaccharides of Xenorhabdus nematophilus (Enterobacteriaceae) and their haematocytes toxicity in nonimmune Galleria mellonella. J Ger Microb 134:1017-1028

El-Maasarawy SAS, Abd El-Baki SM, Salama RAK (1995) Abnormalities of larval haemocytes of Corcyra cephalonica (staint.) after exposure of egg to gamma irradiation. Bull Ent Soc Egypt 73:107-119

El-Sonbaty SM, Gabarty A, Ibrahim AA (2016) Hematological and protein response of Spodoptera littoralis (Boisd.) to gamma radiation and the entomopathogenic fungus Metarhizium anisopliae. Egy J Biol Pest Cont 26(1): $127-137$

Gaugler R (2002) Entomopathogenic nematology. CABI Publishing, Wallingford, UK 
Gaugler R, Kaya HK (1990) Entomopathogenic nematodes in biological control. CRC Press, Boca Raton, Florida, Pp, pp 365-396

Glazer I, Lewis EE (2000) In: Navon A (ed) Bioassays for entomopathogenic nematodes. In Bioassays for Entomopathogens and Nematodes. Kluver Academic Publisher, Holland

Lackie AM (1988) Haemocyte behavior. Adv. Insect Physiol 21:85-178

Lavine MD, Strand MR (2002) Insect hemocytes and their role in immunity. Insect Biochem Molec 32:1295-1309

Laznik Z, Trdan S (2017) The influence of herbicides on the viability of entomopathogenic nematodes (Rhabditida: Steinernematidae and Heterorhabditidae). Int J Pest Manag 63(2):105-111

Laznik Z, Vidrih M, Trdan S (2012) The effect of different entomopathogens on white grubs (Coleoptera: Scarabaeidae) in an organic hay-producing grassland. Arch Biol Sci 64(4):1235-1246

Matha V, Grubhoffer L, Weyda F, Herliianova L (1990) Detection of B-1,3 glucanspecific lectin on the surface of plasmatocytes, immunocompetent cells of great wax moth, Galleria mellonella L. Cytobios 64(256):35-42

Mukherjee K, Altincicek B, Hain T, Domann E, Vilcinskas A, Chakraborty T (2010) Galleria mellonella as a model system for studying Listeria pathogenesis. Appl Environ Microbiol 76(1):310-317

Ribeiro C, Vignes M, Brehélin M (2003) Xenorhabdus nematophila (Enterobacteriacea) secretes a cationselective calcium-independent porin which causes vacuolation of the rough endoplasmic reticulum and cell lysis. J Biochemistry 278(5):3030-3039

Rizk SA (1991) Effect of gamma radiation and some insecticides on the cotton leaf worm, Spodoptera littoralis (Boisd.). M.Sc. Thesis, Faculty of Science, Cairo University.

Salem HM, Hussein MA, Hafez SE, Hussein MA, Sayed RM (2014) Ultrastructure changes in the haemocytes of Galleria mellonella larvae treated with gamma irradiated Steinernema carpocapsae BA2. J Rad Res Appl Sci 7(1):74-79

Salem HM, Hussein MA, Hafez SE, Rizk SA, Sayed RM (2008) Susceptibility of irradiated Galleria mellonella $F_{1}$ larvae to entomopathogenic nematodes. Ninth Arab Conference on the Peaceful Uses of Atomic Energy, Beirut, 3-6 Deceber 2008 pp.: 149-158.

Salt G (1970) The cellular defense reaction of insects. Cambridge Monograph in Experimental Biology, no.16

Sayed RM (2008): Effect of gamma radiation and entomopathogenic nematodes on greater wax moth, Galleria mellonella (Linnaeus) [Lep.: Pyralidae]). M.Sc thesis, Faculty of Science - Ain Shams University. http://www.iaea.org/inis/ collection/NCLCollectionStore/_Public/40/026/40026052.pdf

Sayed RM (2011) Combined effect of gamma radiation and an entomopathogenic nematode on some stored product pests). Ph.D. thesis, Faculty of Science - Ain Shams University. http://www.iaea.org/inis/ collection/NCLCollectionStore/_Public/45/099/45099886.pdf

Sayed RM, Khidr AA, Moustafa HZ (2015) Changes in defense mechanism related to controlling Spodoptera littoralis larvae by gamma irradiated Steinernema carpocapsae BA2. J Ent Res 39(4):287-292

Souka S, Morsi A, Abdel-Rahman A, Rizk S (1993) The effect of gamma radiation and certain insecticides on the total hemocytes counts and its different types in larvae of the cotton leaf worm Spodoptera littoralis (Boisd.). Arab J Nucl Sc Appl 26(2):99-113

\section{Publisher's Note}

Springer Nature remains neutral with regard to jurisdictional claims in published maps and institutional affiliations.

\section{Submit your manuscript to a SpringerOpen ${ }^{\circ}$ journal and benefit from:}

- Convenient online submission

- Rigorous peer review

- Open access: articles freely available online

- High visibility within the field

- Retaining the copyright to your article

Submit your next manuscript at $\boldsymbol{\nabla}$ springeropen.com 